Available online at JSJ: Jurnal Studi Jurnalistik http://journal.uinjkt.ac.id/index.php/jsj

JSJ: Jurnal Studi Jurnalistik, 1 (1), 2019, 25-36

\title{
Pengembangan Proses Pembelajaran SMK Melalui New Media di Kota Bengkulu
}

\author{
Andy Makhrian \\ Program Studi Jurnalistik FISIP Universitas Bengkulu \\ andy.unib@gmail.com
}

\begin{abstract}
ABSTRAK
Education is a very important thing in human life. The progress of a nation is also determined by the progress of its education, the current education system has begun to follow the times, namely by using information technology, or information technology-based education. One of the information technology phenomena today isnew media ornew media. Inthe world ofeducation, there is now aukonline education startup called quipper school. Quipper school tries to become the most complete online learning platform in indonesia that can be used not only for students but also for teaching staff.

The only upper secondary education institution that uses quipper school media in the bengkulu city is currently state vocational high school 3 . State vocational school 3 bengkulu city is a national standard school with an education system based on skills or skills. Through quipper school media teachers can provide information about lessons directly to groups of students at the same time without having to face to face directly. This study proves that the use of quipperschoolmediahas asignificanteffecton the development of learning for students of smk negeri 3 kota bengkulu, then quipper school's media display is very interesting, making students interested in using quipper school media in helping the learning process.
\end{abstract}

Keywords: New Media, Learning Process, and Vocational High School Permalink/DOI: http://doi.org/10.15408/jsj.v1.13931

\section{PENDAHULUAN}

Pendidikanmerupakansuatuhalyangsangat penting dalam kehidupan manusia. Kemajuan suatu bangsa juga ditentukan dari kemajuan pendidikannya, sistem pendidikan saat ini sudah mulai mengikuti perkembangan zaman yaitu dengan banyak menggunakan teknologi informasi, atau pendidikan yang berbasis teknologi informasi. Salah satu fenomena teknologi informasi saat ini adalah New Media atau media baru. Media sosial danmanusiabisadianalogikansepertikendaraan dan bahan bakarnya, sudah menjadi satu kesatuan yang tidak bisa dipisahkan.

Ditunjang dengan munculnya smartphone atau handphone android yang memang difasilitasi dengansisteminternetuntukmediasosialmembuat setiap orang makin sering mengakses media sosial tanpa menggunakan PC komputer atau laptop, cukup dengan handphone setiap orang masingmasing. Berdasarkan studi yang dilakukan The Pew Internet and American Life Project, sejak tahun 2008 sms terus meningkat di kalangan remaja. SMS telah mengalahkan penggunaan email, dantentusajatatapmukasecaralangsung. 
Dengan demikian potensi media sosial sebagai media telekomunikasi kini berubah menjadi suatu kebiasaan yang menggantikan sms karena dengan adanya internet dalam handphone memudahkan penggunannyauntuk berselancardi duniamaya.

Perkembangan teknologi informasi, dengan media sosial sebagai salah satu produk yang mendorong keterbukaan informasi dan kebebasan berpendapat, telah membawa pengaruh besar bagi dinamikakehidupanmasyarakatmasakini.Dengan keberadaan teknologi kini memiliki peranan yang sangatbesar terutama dalam proses pembelajaran di duniapendidikan.Berbagaikemudahandidapatkan setelahadanyapenggunaanteknologiinformasi.

Dalam dunia pendidikan, saat ini telah hadir Startup edukasi online asal Inggris yang disebut dengan Quipper School. Quipper School mencoba untuk menjadi platform pembelajaran online terlengkap diIndonesiayangdapatdigunakantakhanyabagi siswa namun juga bagi para tenaga pengajar. Secara umum, Quipper merupakanstartupedukasi yang cukupmenarik.Perludiketahui,Quippermemiliki lima produk aplikasi e-learning seperti Quipper Quiz, StraightAce, Quipper Courses, Gakumo, dan juga Quipper School yang kini bisa dinikmati dalam bahasa Indonesia.

Quipper didirikan pada tahun 2010 oleh Masayuki Watanabe yaitu pendiri dan CEO dari perusahaan pendidikan yang berpusat di London Inggris.Ada 3 kekuatanpendorongyangmembuat Quipper tercipta. Quipper School telah berusaha untuk mengatasi dan memecahkan tantangantantangan berat tersebut. Dan hasilnya, Quipper School memiliki retention rate (tingkat keberlanjutan) dan viral rate (tingkat penyebaran) yang tinggi. Yang menandakannya adalah begitu para guru mulai menggunakan layanan Quipper School, mereka akan langsung menyukainya, danbersediauntuk terus menggunakannya dalam waktu yanglama.

Paragurutersebutjugamemilikikoneksiyang luasdanbaik, sehingga mereka cenderungsaling berbagi ide. Banyak sekali pengguna awal yang telah memperkenalkan Quipper School kepada rekan gurumereka, yangselanjutnyamenciptakanefek penyebaran. Beberapa darimerekabahkan adayang secarasukarelamembuatvideotutorialdankonten pembelajaran sendiri. Quipper School merupakan platform penghubung antara siswa dan guru dalam pembagian tugas secara online. Layanannya diklaim sesuai dengan pelajaran yang diadaptasi dari kurikulum yang berlaku di Indonesia, tak ayal mata pelajaran yang umum ditemukan seperti Bahasa Indonesia, Bahasa Inggris, Matematika, IPA, dan IPS tersedia di Quipper School. Sesuai dengan keterangannya saatini, Quipper School hanyabisa dinikmatiolehsiswa Sekolah Menengah Tingkat Atas mulai dari kelas 10 hingga kelas 12 .

Satu-satunya lembaga pendidikan menengah ke atas yang menggunakan media Quipper School di Kota Bengkulu saat ini adalah SMK Negeri 3. SMK Negeri 3 Kota Bengkulu merupakan sekolah yang berstandar nasional saat ini dengan sistem pendidikan yang berbasis kepada skill atau keterampilan. Melalui media Quipper School guru dapat memberikan informasi mengenai pelajaran secara langsung kepada group siswa (kelompok kelas) pada waktu bersamaan tanpa harus bertatap muka secara langsung. Melalui media Quipper School peneliti ingin mengetahui bagaimana pemanfaatan media Quipper School di SMK Negeri 3 Kota Bengkulu dalam meningkatan kualitas belajar bagi para siswa atau pelajar.

\section{NEW MEDIA}

Karjaluoto(2008:2) mengungkapkanbahwa istilah media sosial menggambarkan sebuah media sehingga para pengguna dapat dengan mudah berpartisipasi dan memberi kontribusi di dalam media tersebut. Karakteristik umum yang dimiliki setiap media sosialyaitu adanya keterbukaan dialog antar para pengguna. Sosial media dapat dirubah oleh waktu dan diatur ulang oleh penciptanya, atau dalam beberapa situs tertentu, dapat diubah 
olehsuatukomunitas.Selainitusosialmediajuga menyediakan dan membentuk cara baru dalam berkomunikasi.

Seperti diketahui, sebelum muncul dan populernya media sosial, kebanyakan orang berkomunikasidengancarasmsatautelponlewat handphone.Namunsekarangdenganadanyamedia sosial, orang cenderung berkomunikasi lewat layanan obrolan (chat) atau berkirim pesan lewat layanan yang tersedia di media sosial. Menurut Wikipedia, media sosial adalah sebuah media online, dengan para penggunanya bisa dengan mudahberpartisipasi,berbagi, danmenciptakanisi meliputiblog,jejaringsosial,wiki,forumdandunia virtual. Blog, jejaring sosial dan wiki merupakan bentukmediasosialyangpalingumumdigunakan oleh masyarakat di seluruh dunia.

Andreas Kaplan dan Michael Haenlein mendefinisikan media sosial sebagai "sebuah kelompok aplikasi berbasis internet yang membangun di atas dasar ideologi dan teknologi Web 2.0, dan yang memungkinkan penciptaan dan pertukaran user-generated content". Dalam wikipedia media sosial mempunyai ciri-ciri sebagai berikut, pertama pesan yang di sampaikan tidak hanyauntuksatuorangsajanamunbisakeberbagai banyak orang contohnya pesan melalui SMS ataupuninternet. Keduapesanyangdisampaikan bebas, tanpa harus melalui suatu Gatekeeper. Ketiga pesanyangdisampaikancenderunglebihcepatdi bandingmedialainnya. Terakhirpenerimapesan yang menentukan waktu interaksi.

Berdasarkan pendapat dari Schramm (dalam Fajar, 2011) bahwa situasi atau perkembangan media di Dunia sangatbergantung kepada evolusi dari kebutuhan antar generasi. Penulis mencoba merekonstruksi kembalipendapat evolusi media tersebut dan mengejewantahkan berdasarkan empat generasi media, sebagai berikut pertama Media generasi pertama; sebagai acuan media di era ini ditandai dengan adanya tulisan seperti peta harta karun, gambar di gua dengan huruf kuno (hieroglyph di Mesir dan Piktograph di Cina), prasasti, acta diurna dan senatus di Yunani Kuno, Media generasi kedua, ditandai dengan adanya penemuan mesin cetak oleh Johannes Gutenberg;padagenerasiinilahmunculsuratkabar tercetak, buku-buku teks, media cetak terbitan. Selama lebih dari 300 tahun media ini hadir dan menghadirkan kebudayaan baru di masyarakat, Media generasi ketiga; ditandai dengan penemuan tabung-tabung elektronik yang dapat ditangkap olehindra pendengar (radio), penglihatan (slide, film atau foto), kombinasi pendengaran dan penglihatan(film, televisi, rekaman video). Media tertua dalam generasi ini berumur 100 tahun, sedangkan yang termuda 35 tahun. Bahkan, di negara dunia ketiga; media generasi ini masih mendominasi pengelolaan informasi, dan Media generasi keempat, ditandai dengan ditemukannya komputer dan jaringan internet. Media pada generasi ini pun berevolusi menjadi media sosial (istilah sebagian orang sebagai media baru), tetapikeberadaanmediainisangatberbedadengan media generasi sebelumnya.

Padaawalnyamediahanyaperpanjangan indra (dalam istilah McLuhan disebut sebagai the extension of man), media sosialmenjadikanpola komunikasi antarpribadi dan komunikasi massa menjadi terpangkas; simplifikasinya adalah terjadi apa yang disebut Communications Mediating Computer (komunikasi termediasi olehkomputer). Kehebatan media yang sebelumnya yang hanya dapatditangkapindrawi penglihatan,pendengaran, atau kombinasi, pada generasi ini perasaan kognisi hingga psikomotorik dapat ditumpahkan. Batas antara realitas danpseudo realitas menjadi hanya ranah kejiwaan si pengguna media.

\section{MEDIA QUIPPER SCHOOL}

Quipper School adalah startup edukasi online asal Inggris. Mengusung nama Quipper School, Quipper mencoba untuk menjadi platform 
pembelajaran online terlengkap di Indonesia yang dapatdigunakantakhanyabagisiswanamunjuga bagi para tenaga pengajar.

Secara umum, Quipper merupakan startup edukasi yang cukup menarik. Perlu diketahui, Quipper memiliki lima produk aplikasi e-learning seperti Quipper Quiz, StraightAce, Quipper Courses, Gakumo, danjuga Quipper School yang kinibisa dinikmati dalam bahasa Indonesia.

Quipper didirikan pada tahun 2010 oleh Masayuki Watanabe yaitu pendiri dan CEO dari perusahaan pendidikan yang berpusat di London Inggris.Ada 3 kekuatanpendorongyangmembuat Quipper tercipta. Pertama, ingin berbuat sesuatu tentang 'kemiskinan ilmu' yang muncul karena faktor kemalangan seorang anak karena dilahirkan dari keluarga miskin. Masayuki Watanabe sangat terkejutmelihatkeadaantersebutdaripengalaman menjadi relawan membantu orang-orang yang kurang beruntung.

Kedua, Masayuki Watanabe merasa internet dan pendidikan adalah pasangan yang cocok. Dengan menggunakan internet, kecerdasan seorang guru dapat menyentuh hidup jutaan pelajar, dan biaya marjinalnya mendekati angka nol. Dengan mengumpulkan data pengguna dapat beradaptasi dan menyesuaikan pengalaman belajar. Performa dan hasil belajar dapat diukur secara cepat, danprosesbelajarmengajardapatmenjadi lebih kolaboratif, inklusif dan menyenangkan daripada sebelumnya dan Masayuki Watanabe merasainiwaktuyangtepatbagi Quipper.Dengan menurunnyabiayaperangkatteknologidansemakin menyebarnya perangkat berbasis internet serta bervariasinya pengalaman mengerjakan proyek online membuatnya merasa bahwa waktu yang sempurna akhirnya tiba.

Quipper School telah berusaha untuk mengatasi dan memecahkan tantangan-tantangan berat tersebut. Dan hasilnya, Quipper School memiliki retention rate (tingkat keberlanjutan) dan viral rate (tingkat penyebaran) yang tinggi. Yang menandakannya adalah begitu para guru mulai menggunakan layanan Quipper School, mereka akan langsung menyukainya, dan bersedia untuk terus menggunakannya dalam waktu yanglama.

Paragurutersebutjugamemilikikoneksiyang luasdanbaik, sehingga mereka cenderung saling berbagi ide. Banyak sekali pengguna awal yang telah memperkenalkan Quipper School kepada rekan gurumereka, yangselanjutnyamenciptakanefek penyebaran. Beberapa dari mereka bahkan ada yang secara sukarela membuat video tutorial dan konten pembelajaran sendiri.

Quipper School telah bekerja sangat erat dengan Benesse, raksasa pendidikan di Jepang, untuk melihat mana yang dapat digunakan dan mana yang tidak. Dalam proses tersebut, Quipper School telah menyerap banyak data pembelajaran dari pengguna kolektif. Menggunakan penelitian yang tepat, Quipper School banyak belajar mengenai bentuk dari pembelajaran adaptif (yang benar), dan pedidikan yang dikemas dengan game (yang benar) secara langsung.

Hingga detik ini, Quipper School telah digunakan oleh lebih dari 9 juta pelajar, dan mereka telah mengerjakan lebih dari 250 juta soal. Quipper telah mengumpulkan dana sebesar lebihdari\$10Mdariperusahaanpemodalternama seperti Atomico di London, dan Globis Capital Partners di Tokyo. Dan sekarang telah memiliki kantor-kantor di London, Tokyo dan Manila, dan berkembang sangat pesat.

Quipper School merupakan platform penghubungantarasiswadangurudalampembagian tugas secara online. Layanannya diklaim sesuai dengan pelajaran yang diadaptasi dari kurikulum yangberlakudiIndonesia, takayalmatapelajaran yangumumditemukanseperti Bahasa Indonesia, Bahasa Inggris, Matematika, IPA, dan IPS tersedia di Quipper School. Sesuai dengan keterangannya, saat ini, Quipper School hanya bisa dinikmati oleh siswakelasSMAmulaidarikelas 10hinggakelas 12.

$$
\text { Quipper School memiliki dua bagian }
$$




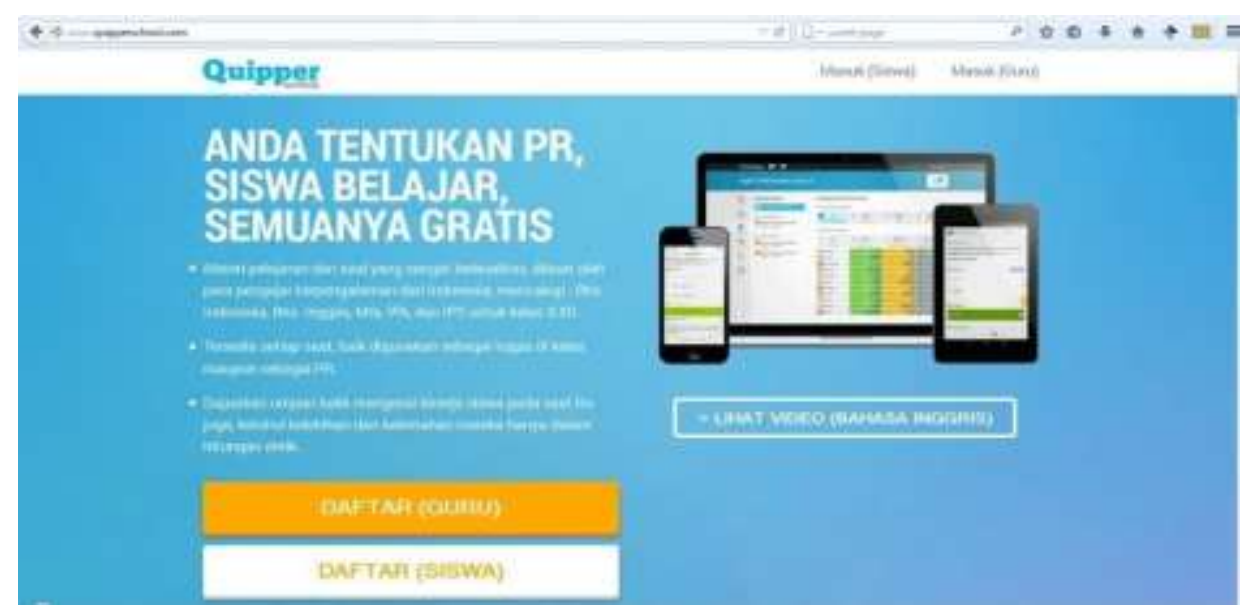

Gambar. 1 Interface Quipper School

suatu keterampilan, yaitu keterampilan tangan. Pada abad kesembilan belas dimunculkan konsep baru tentang pendidikan kejuruan, yaitu dengan dimasukkannya pendidikan kejuruan ke dalam pemberdayaan profesional, seperti halnya hukum, profesi keinsinyuran, kedokteran,

yaitu Quipper School Link yangdisediakanuntuk keperawatan dan profesional lainnya.

Pendidikan kejuruan adalah pendidikan guru, dan juga Quipper School Learn yang bisa diakses bagi siswa. Secara singkat, Quipper School Link memudahkanparaguruuntukdapatmengirim tugas ke perangkat mobile milik siswa sekaligus juga dapat memantau perkembangan belajarnya secara online. Sementara itu, Quipper School Learn disediakan sebagai tempat siswa untuk mengerjakan dan men-submit tugas yang diberikan. Dalam Quipper School Learn siswa bisa mengkoleksi ragam temayangdihargaidalamsejumlahkointertentu.

\section{SEKOLAH MENENGAH KEJURUAN}

Sekolah Menengah Kejuruan (SMK) adalah salah satu bentuk satuan pendidikan formal yang menyelenggarakan pendidikan kejuruan pada jenjang pendidikan menengah sebagai lanjutan dari SMP/MTsataubentuklainyangsederajatatau lanjutan dari hasil belajar yang diakui sama/setara SMP/MTs.DiSMKterdapatbanyaksekaliProgram Keahlian.Sekolah Menengah Kejuruan atau yang disebut SMK adalah bagian terpadu dari Sistem Pendidikan Nasional, yang mempunyai peranan penting didalam menyiapkan dan pengembangan Sumber Daya Manusia (SDM).

Awal pendidikan kejuruan didefinisikan sebagai "vocational educational is simply training forskills, training thehands". Pendidikankejuruan merupakan latihan sederhana untuk menguasai non akademis yang berorientasi pada praktekpraktek dalam bidang pertukangan, bisnis, industri, pertanian, transportasi, pelayanan jasa, dan sebagainya. Dalam Undang-undang Sistem Pendidikan Nasional (UUSPN) No. 20 tahun 2003 pasal15 menyatakanbahwapendidikankejuruan adalah pendidikan menengah yang mempersiapkan pesertadidik terutamauntukbekerjadalambidang tertentu.

Pendidikan kejuruan adalah pendidikan yang menghubungkan, menjodohkan, melatih manusia agar memiliki kebiasaan bekerja untuk dapatmemasukidanberkembangpadaduniakerja (industri), sehingga dapat dipergunakan untuk memperbaiki kehidupannya.

Pendidikan kejuruan berhubungan dengan mempersiapkan seseorang untuk bekerja dan dengan memperbaikipelatihanpotensitenagakerja.Halini meliputi berbagai bentuk pendidikan, pelatihan, atau pelatihan lebih lanjut yang dibentuk untuk mempersiapkan seseorang untuk memasuki atau melanjutkan pekerjaan dalam suatu jabatanyang sah. Dapat dikatakan pendidikan kejuruan (SMK) adalah bagian dari sistem pendidikan nasional yang bertujuan mempersiapkan tenaga yang memiliki keterampilan dan pengetahuan sesuai dengankebutuhan persyaratan lapangankerjadan mampu mengembangkan potensi dirinya dalam 
mengadopsi dan beradaptasi dengan perkembangan teknologi.Dalamprosespendidikankejuruanperlu ditanamkan pada siswa pentingnya penguasaan pengetahuandanteknologi,keterampilanbekerja, sikap mandiri, efektif dan efisien dan pentingnya keinginansuksesdalamkarirnyasepanjanghayat. Dengankesungguhandalammengikutipendidikan kejuruan maka para lulusan kelak dapat menjadi manusiayangbermartabatdanmandirisertamenjadi warga negara yang mampu membayar pajak.

Pada dasarnya pendidikan kejuruan berdasarkan kebutuhan nyata pasar keja. Untuk dapatmerealisasikanprograminimakaperanserta duniausahadanindustrisangatdiperlukan.Bahkan perlu mendudukkan mereka dalam posisi yang penting, sehingga program kejuruan ditawarkan benar-benarsesuaidengankebutuhan.Lebihlanjut dijelaskan bahwa sistem pendidikan kejuruan yang memberikan standar kompetensi nasional yang baku. Standar kompetensi, standar kurikulum dan standarpengujiandimaksudkanuntukmenjamin bahwa sistem pendidikan kejuruan benar-benar memberikan kompetensi yang telahdibutuhkan oleh industri. Oleh karenanya ukuran mutu tamatan pendidikan kejuruan tidak hanya dilihat dari hasil Ujian Akhir Nasional., tetapi juga dari kompetensi yang dicapai. Ketercapaian kompetensi dilihatdariketerampilan.Setiapketerampilanyang dicapai diberikan sertifikat oleh lembaga yang berwenang seperti majelis pendidikan kejuruan nasional (MPKN).

UUSPN No. 20 tahun 2003 pasal 15, menyatakan pendidikan menengah kejuruan bertujuanuntukmenyiapkanpesertadidikterutama untuk bekerja dalam bidang tertentu. Tujuan tersebut dapat dijabarkan lagi oleh Dikmenjur (2003) menjadi tujuan umum dan tujuan khusus, tujuan umum sebagai bagian dari sistem pendidikan menengah kejuruan SMK bertujuan, menyiapkan peserta didik agar dapat menjalani kehidupan secara layak, meningkatkan keimanan dan ketakwaan peserta didik, menyiapkan peserta didik agar menjadi warga negara yang mandiri dan bertanggung jawab, menyiapkan peserta didik agar memahami dan menghargai keanekaragaman budaya bangsa Indonesia, dan menyiapkan peserta didik agar menerapkan dan memelihara hidup sehat, memiliki wawasan lingkungan, pengetahuan dan seni.

Tujuan khusus, SMK bertujuan menyiapkan peserta didik agardapat bekerja, baik secara mandiri ataumengisilapanganpekerjaanyangadadidunia usaha dan industri sebagai tenaga kerja tingkat menengah, sesuai dengan bidang dan program keahlian yangdiminati, membekali peserta didik agar mampu memilih karir, ulet dan gigih dalam berkompetensi dan mampu mengembangkan sikap profesional dalam bidang keahlian yang diminati, dan membekali peserta didik dengan Ilmu Pengetahuan dan Teknologi (IPTEK) agar mampu mengembangkan diri sendiri melalui jenjang pendidikan yang lebih tinggi.

Kompetensi lulusan pendidikan kejuruan sebagai subsistem dari sistem pendidikan nasional adalah penghasil tamatan yang memiliki keterampilan dan penguasaan IPTEK dengan bidang dari tingkat keahlian yang sesuai dengan kebutuhan pembangunan, penghasil tamatan yang memiliki kemampuan produktif, penghasil sendiri, mengubahstatustamatandaristatusbeban menjadi aset bangsa yang mandiri, penghasil penggerak perkembangna industri Indonesia yang kompetitif menghadapi pasar global, penghasil tamatan dan sikap mental yang kuat untuk dapat mengembangkan dirinya secara berkelanjutan. Hasil kerjapendidikanharusmampumenjadipembeda dari segi unjuk kerja, produktifitas, dan kualitas hasilkerjadibandingkandengantenagakerjatanpa pendidikan kejuruan.

Jadipendidikankejuruanadalahsuatulembaga yang melaksanakan proses pembelajaran keahlian tertentu beserta evaluasi berbasis kompetensi, yangmempersiapkansiswamenjaditenagakerja setingkat teknisi. 


\section{MODEL PENELITIAN}

Penelitian ini mengenai pengembangan proses pembelajaran smk melalui New Media di Kota Bengkulu khususnya Media Quipper School dalam peningkatan kualitas pembelajaran di SMK Negeri 3 Kota Bengkulu. Peneliti menfokuskan pada jenis penelitian kuantitatif. Penelitian kuantitatif menyajikan data dalam bentuk deskripsi dengan menggunakan informasi berupa angka-angka statistik. Metode yang di gunakan adalah survei. Surveiadalahmetoderisetdenganmenggunakan kuesioner sebagai instrument pengambilan datanya (Krisyantono, 2008:57).

Riset kuantitatif menggambarkan atau menjelaskan suatu masalah yang hasilnya dapat digeneralisasikan (Krisnyantono, 2008 : 57), metode kuantitatif adalah metode penelitian yang menggunakan kuesioner sebagai instrument utama pengumpulan datanya. Tujuannya untuk memperoleh informasi tentang sejumlah responden yang dianggap mewakili populasitertentu.

Seperti yang dikemukakan oleh Sugiyono (2003),bahwa"Penelitiankuantitatifmerupakan prosedur penelitian yang menghasilkan data kuantitatif berupa angka-angka dari perhitungan statistik. Dalam penelitian ini penggunaan pendekatan kuantitatif dilakukan untuk mengetahui pemanfaatan media quipper school dalam peningkatan kualitas pembelajaran di SMK Negeri 3 Kota Bengkulu.

\section{POPULASI DAN SAMPEL}

Populasi menurut Kriyantono (2006:149) adalah keseluruhan objek atau fenomena yang diteliti.Populasidalampenelitianiniadalahseluruh Siswa Negeri 3 Kota Bengkulu.

Tabel 1. Daftar siswa/i SMK Negeri 3 Kota Bengkulu yang menggunakan media Quipper School

\begin{tabular}{|c|c|c|}
\hline No & Kelas & Jumlah Siswa/i \\
\hline 1 & X & 278 \\
\hline 2 & XI & 295 \\
\hline 3 & XII & 289 \\
\hline Jumlah & & 862 \\
\hline
\end{tabular}

Sumber : Pra Penelitian Februari 2017

Metode pengambilan sampel yang digunakan adalah proporsional random sampling berimbang sebesar 20\%. Karena pemilihan sampel secara proporsional ini juga mempertimbangkan jenis kelamin responden, maka jumlah dari sampel penelitianyangakandigunakanataudiambildalam penelitian ini adalah sebanyak 100 orang siswa dimana respondenberjenis kelamin laki-laki dan perempuan akan diambil dengan proporsi yang relatifsama,yakni50orangsiswalaki-lakidan 50 orang siswa perempuan dan sampel hanya untuk kelas 10 dan 11. Untuk kelas 12 tidak dijadikan sampel pada penelitian ini karena saat ini pada bulan april sudah melakukan ujian nasional dan sudah banyak yang mendaftar ke perguruan tinggi baik dalam dan diluar ProvinsiBengkulu.

\section{DEFINISI KONSEPTUAL}

Definisi konseptual atas variabel penelitian yang digunakandalampenelitianiniadalahpenggunaan media Quipper School adalah media edukasi yang menghubungkan antara siswa dan guru dalam pembagian tugas belajar dan pekerjaan rumah secara online, pemenuhan kebutuhan informasi adalahserangkaiantindakanyangdilakukanuntuk memenuhikebutuhaninformasimelaluipencarian, mendengarkan, membaca, mempertimbangkan, mengungkapkan yang sudah diperoleh dan kemudian menggunakannya. 


\section{DEFINISI OPERASIONAL}

Secara operasional, masing-masing variabel penelitiandiukurdandirumuskansebagaiberikut:

1. Variabel pengaruh (X) adalah penggunaan media Quipper School yang diukur melalui indikator:
a) Frekuensi penggunaan media
b) Intensitas pengguna media
c) Jumlah informasi yangdisampaikan
d) Format media yang menarik

2. Variabel terpengaruh(Y) adalah pemanfaatan Media Quipper School dalam peningkatan kualitas pembelajaran di SMK Negeri 3 Kota Bengkulu dalam hal ini para pelajar yang diukur melalui indikator:
a) Informasi mengenai pelajaran
b) Informasi mengenai tugas
c) Informasi mengenai kegiatan belajar mengajar
d) Informasi mengenai ekstrakurikuler

\section{TEKNIK PENGUMPULAN DATA}

Untuk memperoleh hasil penelitian yang benar dan dapat dipertanggungjawabkan, maka dalam penelitian ini data dikumpulkanmenurut cara perolehan data yaitu data primer dan data sekunder. Data Primer yaitu data yang diperoleh dari lapangan atau data yang diperoleh secara langsungdariobjekpenelitianmelaluiyangpertama Observasi, observasi merupakan metode yang digunakan dengan cara mengadakan pengamatan secara langsung terhadap fenomena-fenomena yang terdapat pada objek penelitian. Observasi dilakukan dengancaramelihatlangsungpenggunaanmedia Quipper School oleh siswa dan guru SMK Negeri 3 Kota Bengkulu. Yang kedua kuesioner, penyebaran kuesioner dilakukan secara langsung pada siswa dan guru SMK Negeri 3 Kota Bengkulu sebagai objek penelitian. Kuesioner yang disebarkan berisikan pertanyaan-pertanyaan berkaitan dengan penggunaan media sosial dan pemanfaatan Media Quipper School dalam peningkatan kualitas pembelajaran. Studi Kepustakaan, studi kepustakaan merupakan data yang diperoleh dari penelitian kepustakaan menggunakan referensi buku, jurnal dan kepustakaan lainnya yang berkaitan dengan penelitian. Terakhir Dokumentasi, dokumentasi merupakan teknik pengumpulan data dengan cara mencatat, atau membukukan dari keteranganketeranganataudokumenyangterdapatditempat penelitian. Dokumentasi juga dapat berupa data foto-foto penelitian dan sebagainya yang berkaitan dengan kegiatan penelitian.

Data Sekunderyaitudatayangdiperolehdari sumberkeduaatausumbersekunderdaridatayang dibutuhkan (Bungin, 2008). Data sekunder didapat daripenelusuranonlinedisitus-situspenyediadata.

\section{TEKNIK ANALISIS DATA}

Analisis data yang digunakan dalam penelitian ini adalah analisis kuantitatif. Analisis kuantitatif adalah metode analisis data penelitian dengan cara melakukan perhitungan angka-angka statistik. Analisis kuantitatif yang digunakan adalah analisis regresi linier sederhana dan analisis korelasi.

Teknik uji regresi menurut Burhan Bungin (2008) adalah proses analisis persamaan garis yang diperoleh berdasarkanperhitungan-perhitungan statiska, umumnya disebut model, untuk mengetahui bagaimana perbedaan sebuah variabel mempengaruhi variabel lain.

Analisis regresi linier sederhana digunakan untuk mengetahui pengaruh penggunaan media Quipper School terhadap pemenuhan kebutuhan informasi, dengan persamaan sebagai berikut:

$$
\mathbf{Y}=\mathbf{a}+\mathbf{b X}
$$

Keterangan :

$\mathrm{Y}=$ VariabelTerpengaruh/Dependen

$\mathrm{a}=$ Konstanta 
$\mathrm{X}=$ Variabel Pengaruh/Independen

$\mathrm{b}=$ Koefisien regresi variabel penggunaan media sosial

Untuk menghitung a dan b digunakan persamaan sebagai berikut :

$$
\begin{aligned}
& \mathrm{a}=\frac{\sum \mathrm{Y}\left(\sum \mathrm{X}^{2}\right)-\left(\sum \mathrm{X}\right)\left(\sum \mathrm{X}\right)}{\mathrm{n} \sum \mathrm{X}^{2}-\left(\sum \mathrm{X}\right)^{2}} \\
& \mathrm{~b}=\frac{n}{n \sum \underline{\mathrm{X}}-\underline{\sum} \underline{X} \underline{\sum} \underline{Y} \underline{Y}}
\end{aligned}
$$

Sedangkan untuk mengukur besarnya hubungan antara variabel $\mathrm{x}$ dengan variabel $\mathrm{y}$ digunakan analisis korelasi dengan rumus sebagai berikut :

$$
\mathrm{R}=\frac{n \sum \underline{X}-\left(\underline{\sum X Y} \underline{\sum} \underline{Y}\right)}{\sqrt{\left\{n \sum X^{2}-\left(\sum X\right)^{2}\right\}}\left\{n \sum Y^{2}-\left(\sum Y\right)^{2}\right\}}
$$

Keterangan :

$\mathrm{R}=$ Jumlah Koefisienkorelasi

$\mathrm{n}=$ Banyaknya Sampel

$\mathrm{X}=$ Variabel Pengaruh/Independen

$\mathrm{Y}=$ Variabel Terpengaruh/Dependent

\section{PENGEMBANGAN PROSES}

\section{PEMBELAJARAN SMA MELALUI NEW} MEDIA DI KOTA BENGKULU

Penelitian ini fokus pada Pengembangan Proses Pembelajaran SMA Melalui New Media Di Kota Bengkulu khususnya media Quipper School. Penelitian ini mengenai pengembangan proses pembelajaran sma melalui New Media di Kota Bengkulu khususnya Media Quipper School dalam peningkatan kualitas pembelajaran di SMK Negeri 3 Kota Bengkulu.

Media Quipper School adalah startup edukasi online asal Inggris. Media QuipperSchool merupakan media pembelajaran online terlengkap di Indonesia yangdapatdigunakantakhanyabagisiswanamun juga bagi para tenaga pengajar.

Secara umum, Quipper merupakan startup edukasi yang cukup menarik. Perlu diketahui, Quipper memiliki lima produk aplikasi e-learning seperti Quipper Quiz, StraightAce, Quipper Courses, Gakumo, danjuga Quipper School yang kinibisa dinikmati dalam bahasa Indonesia.

Respondendalampenelitianiniadalahpelajar SMKNegeri3 KotaBengkuluyangberjumlah50 orang siswa di mana responden berjenis kelamin laki-laki dan perempuan akan diambil dengan proporsi yang relatif sama, yakni 25 orang siswa laki-laki dan 25 orang siswa perempuan. Metode pengambilan sampel yang digunakan adalah proporsional random sampling.

Berdasarkan hasil penyebaran kuesioner, diperoleh karakteristik responden sebagai berikut.

Tabel 4.1 Karakteristik Responden

\begin{tabular}{|l|r|r|}
\hline Karakteristik Demografi & $\begin{array}{r}\text { Jumlah } \\
\text { (Orang) }\end{array}$ & $\begin{array}{c}\text { Persentase } \\
\text { (\%) }\end{array}$ \\
\hline$\underline{\text { Umur }}$ & 24 & 48 \\
$15-16$ Tahun & 26 & 52 \\
$17-18$ Tahun & $\mathbf{5 0}$ & $\mathbf{1 0 0}$ \\
\hline Jumlah Responden & 25 & 50,00 \\
\hline Jenis Kelamin & 25 & 50,00 \\
\hline Laki-laki & $\mathbf{5 0}$ & $\mathbf{1 0 0}$ \\
Perempuan & & \\
\hline Jumlah Responden & 20 & 40 \\
\hline Kelas & 20 & 40 \\
X & 10 & 20 \\
XI & $\mathbf{5 0}$ & $\mathbf{1 0 0}$ \\
XII & & \\
\hline Jumlah Responden & & \\
\hline
\end{tabular}

Sumber: Hasil Penelitian Oktober 2017

BerdasarkanTabel4.1diketahuibahwajumlah responden perempuan dan responden laki-laki memiliki proporsi yang sama, yakni masing-masing sebanyak 25 orang atau sebesar 50 persen. 
Berdasarkan umur responden, rata-rata responden penelitian berada pada usia 17-18 tahun yakni sebanyak 26 orang atau sebesar 52 persen. Rentang usia ini memang paling banyak dimiliki oleh siswa menengah atas termasuk siswa menengahkejuruan.Sementarauntukusiaantara 15-16 tahun sebanyak 44 orang atau sebesar 48 persen. 50orang siswa responden penelitian tersebut terbagikedalam3kelompokkelas,yaknikelasX, XI dan XII.

Pembahasan difokuskan pada variabel-variabel yang digunakan dalam penelitian, yakni penggunaan media Quipper School dan perkembangan pendidikan bagi pelajar. Berdasarkan pengumpulan data yang didapat di lapangan dapat diketahui jawaban dari masing-masing pertanyaan variabel adalah sebagai berikut:

\section{Penggunaan Media Quipper School}

Tabel 4.2 Penggunaan Media Quipper School

\begin{tabular}{|c|c|c|c|}
\hline No. & Jawaban & Jumlah & Persentase \\
\hline 1. & Sangat Tinggi & 47 & $94 \%$ \\
\hline 2. & Tinggi & 3 & $6 \%$ \\
\hline 3. & Sedang & 0 & $0 \%$ \\
\hline 4. & Rendah & 0 & $0 \%$ \\
\hline 5. & Sangat Rendah & 0 & $0 \%$ \\
\hline Total & & 50 & $100 \%$ \\
\hline
\end{tabular}

Sumber: Hasil Penelitian Oktober 2017

Berdasarkan tabel 4.2 diatas, dapat dilihat bahwa secara keseluruhan jawaban responden untuk variabel penggunaan media Quipper School adalah sangattinggidantinggi,yaitu47orangresponden dengan persentase $94 \%$ menyatakan sangat tinggi dan 3 orang responden dengan persentase $6 \%$ menyatakan tinggi. Hal ini menunjukkan bahwa hampir keseluruhan responden menyatakan sangat setuju dengan penggunaan media Quipper School.
Tabel 4.3 Menggunakan Media Quipper School apabila baru ada tugas dari guru

\begin{tabular}{|c|c|c|}
\hline Pilihan & Jumlah & Persentase \\
\hline SS & 34 & $68 \%$ \\
\hline S & 16 & $32 \%$ \\
\hline KS & - & $0 \%$ \\
\hline TS & - & $0 \%$ \\
\hline STS & - & $0 \%$ \\
\hline \multicolumn{2}{|c|}{ JUMLAH } \\
50
\end{tabular}

Sumber: Hasil Penelitian Oktober 2017

Berdasarkantabel4.3diatas,dapatdisimpulkan bahwa sebagian besar respondenmenggunakan media Quipper School pada saat hanya tugas dari guru mata pelajaran tertentu. Hal ini dapat terlihat dari sebanyak 34 orang dengan persentase $68 \%$ menjawab sangat setuju, 16 orang dengan persentase $32 \%$ menjawab setuju dan tidak ada seorangpun responden yang menjawab kurang setuju, tidak setuju dan sangat tidak setuju untuk menggunakan media Quipper School saat hanya ada informasi tugas dari guru mata pelajaran tertentu.

\section{Kepraktisan Media Quipper School}

Tabel 4.4 Media Quipper School sangat praktis digunakan karena dapat diaksesmelaluiperangkatelektronikyang menggunakan internet seperti handphone, komputer, laptop, notebook

\begin{tabular}{|c|c|c|}
\hline Pilihan & Jumlah & Persentase \\
\hline SS & 43 & $86 \%$ \\
\hline S & 7 & $14 \%$ \\
\hline KS & - & $0 \%$ \\
\hline TS & - & $0 \%$ \\
\hline STS & - & $0 \%$ \\
\hline JUMLAH & 50 & $100 \%$ \\
\hline
\end{tabular}

Sumber: Hasil Penelitian Oktober 2017 
Berdasarkan tabel 4.4 diatas, dapat disimpulkan bahwa sebagian besar responden sangat setuju jika media Quipper School sangat praktis digunakan karena dapat diakses melalui perangkat elektronik yang menggunakan internet seperti handphone, komputer, laptop, notebook, dll. Hal ini dapat terlihat dari sebanyak 43 orang dengan persentase $86 \%$ menjawab sangat setuju, 7 orang dengan persentase $14 \%$ menjawab setuju dan tidak ada seorangpun responden yang menjawab kurang setuju, tidak setuju dan sangat tidak setuju jika media Quipper School sangat praktis digunakan karena dapat diakses melalui perangkat elektronik yang menggunakan internet seperti handphone, komputer, laptop, notebook.

\section{Fungsi Media Quipper School}

Tabel 4.5 Terbantu dengan adanya media Quipper School

\begin{tabular}{|c|c|c|}
\hline Pilihan & Jumlah & Persentase \\
\hline SS & 42 & $84 \%$ \\
\hline S & 8 & $16 \%$ \\
\hline KS & - & $0 \%$ \\
\hline TS & - & $0 \%$ \\
\hline STS & - & $0 \%$ \\
\hline JUMLAH & 50 & $100 \%$ \\
\hline
\end{tabular}

Sumber: Hasil Penelitian Oktober 2017

Berdasarkantabel4.5diatas,dapatdisimpulkan bahwa sebagian besar responden merasa sangat terbantu dengan adanya media Quipper School. Hal ini dapat terlihat dari sebanyak 42 orang denganpersentase $84 \%$ menjawabsangatsetuju, 8 orang dengan persentase $16 \%$ menjawab setuju dan tidak ada seorangpun responden yang menjawab kurang setuju, tidak setuju dan sangat tidak setuju jika cukup terbantu dengan adanya media Quipper School ini.

\section{Tampilan Media Quipper School}

Tabel 4.6 Media Quipper School memiliki tampilan yang menarik dengan fitur-fitur yang mudah dimengerti

\begin{tabular}{|c|c|c|}
\hline Pilihan & Jumlah & Persentase \\
\hline SS & 47 & $94 \%$ \\
\hline S & 3 & $6 \%$ \\
\hline KS & - & $0 \%$ \\
\hline TS & - & $0 \%$ \\
\hline STS & - & $0 \%$ \\
\hline JUMLAH & 50 & $100 \%$ \\
\hline
\end{tabular}

Sumber: Hasil Penelitian Oktober 2017

Berdasarkantabel4.6diatas,dapatdisimpulkan bahwa sebagian besar responden sangat setuju bahwamedia Quipper School memiliki tampilan yang menarik dengan fitur-fitur yang mudah dimengerti. Hal ini dapat terlihat dari sebanyak 47orangdenganpersentase $94 \%$ menjawabsangat setuju, 3 orang dengan persentase $6 \%$ menjawab setuju dan tidak ada seorangpun responden yang menjawab kurang setuju, tidak setuju dan sangat tidak setuju bahwa media Quipper Schoolmemiliki tampilan yang menarik dengan fitur-fitur yang mudah dimengerti.

\section{Kebutuhan Media Quipper School}

Tabel 4.7 Kebutuhan informasi mengenai pelajaran dapat diperoleh dari laman media Quipper School

\begin{tabular}{|c|c|c|}
\hline Pilihan & Jumlah & Persentase \\
\hline SS & 43 & $86 \%$ \\
\hline S & 7 & $14 \%$ \\
\hline KS & - & $0 \%$ \\
\hline TS & - & $0 \%$ \\
\hline STS & - & $0 \%$ \\
\hline JUMLAH & 50 & $100 \%$ \\
\hline
\end{tabular}

Sumber: Hasil Penelitian Oktober 2017 
Berdasarkan tabel 4.7 diatas, dapat disimpulkan bahwa sebagian besar responden sangat setuju jika kebutuhan informasi mengenai pelajaran dapat diperoleh dari laman media Quipper School. Hal ini dapat terlihat dari sebanyak 43 orang dengan persentase $86 \%$ menjawabsangatsetuju, 7 orang denganpersentase $14 \%$ menjawabsetujudantidak ada seorangpun responden yang menjawab kurang setuju, tidak setuju dan sangat tidak setuju jika kebutuhan informasi mengenai pelajaran dapat diperoleh dari laman media Quipper School.

\section{KESIMPULAN DAN SARAN}

Penelitian ini bertujuan untuk mengetahui apakahproses pembelajaran melalui New Media khususnya dengan Media Quipper School bisa berkembang di SMKN 3 Kota Bengkulu. Dari hasil penelitian yang telah dilakukan melalui survei kepada siswa di SMKN 3 Kota Bengkulu yang menjadirespondenpenelitiandandarihasilanalisis yang peneliti dapat dilapangan disimpulkan bahwa penelitian ini membuktikan bahwa penggunaan media Quipper School berpengaruh signifikan terhadap perkembangan pembelajaran bagi pelajar SMK Negeri 3 Kota Bengkulu, selanjutnya tampilan media Quipper School sangat menarik sehingga membuat para siswa menjadi tertarik dalampenggunaan media Quipper School dalam membantu proses belajar.

Terakhir saran dari hasil penelitian ini yaitu pihak atau lembaga sekolah lebih bisa lagi mensosialisasikan media-media pembelajaran yang dapat membantu para siswa dalam tumbuh kembang kemampuan belajar mereka dan para siswa diharapkan bisa lebih kreatif lagi dalam penggunaan media pembelajaran.

\section{DAFTAR PUSTAKA}

Abidin,Yusuf. 2009. Guru dan Pembelajaran Bermutu. Rifki : Bandung.
Bungin, Burhan. 2008. Metode Penelitian Kuantitatif. Gramedia : Jakarta.

Effendy, Onong Uchjana. 2000. Ilmu, Teori dan Filsafat Komunikasi. PT. Citra Aditya Bekasi : Bandung.

Effendy, Onong Uchjana. 2005. Ilmu Komunikasi : Teori dan Praktek, Cetakan Kesembilanbelas, Remadja Rosdakarya : Bandung.

Firmansyah, Aditya. 2010. Situs Jejaring Sosial Menggunakan Elgg. Makalah tidak diterbitkan. Sekolah TeknikElektrodan Informatika. ITB: Bandung.

Heath, Robert L dan Jannings Bryant. 2000. Human Communication Theory and Research, Con-cepts, Contexts, and Challenges. Mahwah, New Jersey-London: Lawrence Erlbaum Associate Publisher.

Kriyantono, Rachmat. 2008. TeknikPraktis Riset Komunikasi. Jakarta.

Mulyana, Deddy. 2007. Ilmu Komunikasi Sebuah Pengantar Edisi Revisi. PT. Remaja Rosdakarya: Bandung.

Rakhmat, Jalaludin. 2002. Metode Penelitian Komunikasi. PT. Remaja Rosdakarya : Bandung.

Rahmat,Jalaluddin,2005. PsikologiKomunikasi. PT . Remaja Rosdakarya : Bandung.

Severin,W.,J.,Tankard,J. 2008.TeoriKomunikasi: Sejarah, Metode, dan TerapandiDalam Media Massa. Penerbit Kencana Prenada Media Group : Jakarta.

Sugiyono. 2011. Metode Penelitian Pendekatan Kuantitatif, Kualitatif dan $R \& D$. Alfabeta : Bandung.

Suryabrata, S. 2003. Metodologi Penelitian. Jakarta: CV Rajawali.

Thoifah, I'anatut. 2015. Statistika Pendidikan dan Metode Penelitian Kuantitatif. Madani Media: Malang. 